\title{
IDENTIFICATION OF PROBLEMS OF IMPLEMENTATION OF LEAN CONCEPT IN THE SME SECTOR
}

\author{
ROBERT UleWicz, ROBERT KuCĘBA
}

\begin{abstract}
A B S T R A C T
The article presents identification of problems during the implementation of Lean concept in small and medium-sized enterprises in Poland. Although the Lean methodology is recognized all over the world as one of the best and most effective ways to improve the functioning of enterprises, in Polish conditions exist serious problems with its implementation. Development of small and medium-sized enterprises is regarded as one of the measures of economic growth and a sign of healthy competition. The needs of the economy and the limited resources characterizing this enterprise sector imply the need to adjust its capacities to the requirements of the turbulent environment. In the analysis of problems there were used the results of questionnaire surveys conducted among representatives of the companies participating in the largest Lean conference in Central Europe.
\end{abstract}

KEY WORDS

Lean, SMEs, improvement, questionnaire survey

DOI: 10.1515/emj-2016-0002

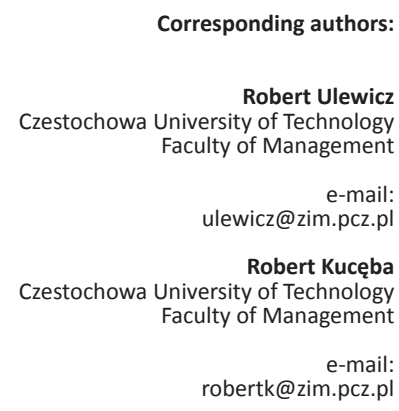

\section{INTRODUCTION}

W. E. Deming in his classic study (Deming, 1982) stated that ",every activity, action, work is a process or a part of some process", and the responsibility of managers is to understand the essence of realized in the company processes and the drive to their continuous improvement. Processes are the essence of any changes, this is due to the complexity of their operation and the processes are a challenge to contemporary organization (Grudowski \& Leseure, 2013). The concept of Lean comes down to the management of the organization by reducing the number of inputs to create the same number of outputs, through the elimination of waste in order to provide greater value for the manufacturer and the customer. Lean significantly improves the operational efficiency of companies with regard to costs, quality as well as delivery mainly in the sector of large enterprises of automotive industry (Engelund et al., 2009; Goncharuk, 2009; Mahalik \& Nambiar, 2010;
Jadhav et al., 2015). In the literature we can meet frequently opinions that Lean concept can be applied in full form in an enterprise in which the specificity of its functioning is closer to the specifics of functioning of the automotive industry (Walentynowicz, 2013). Large companies have greater incentive to implement Lean concept. They also have more resources that can be used in the implementation of this concept. Small and medium enterprises have more difficult task with the implementation. This is due to, inter alia, insufficient resources, lack of knowledge, as well as lack of support in the process of implementation by external companies for which repeatedly small and medium-sized enterprises are not sufficiently attractive from the point of potential profits from implementation.

There are numerous studies on the implementation of Lean in small and medium-sized enterprises in specific industries, mainly the production of 
household appliances and food production (Dora et al., 2013; Dora \& Gellynck, 2015). The question arises: what with other branches? Production of furniture, galvanic-technical plants or ceramic plants employing up to 50 employees with specific technical requirements, which often limit the implementation of Lean solutions in the direct area of production (Kleszcz et al., 2013).

In the Polish economy, small and medium-sized enterprises provide most jobs (69\%, according to Central Statistical Office data from 2013) and constitute $99.8 \%$ of the total number of enterprises. However, Polish small and medium-sized enterprises produce only $50 \%$ of added value of the whole economy in comparison to $58 \%$ for small and medium-sized enterprises across the European Union (Zadura-Lichota, 2014). Presented data show that the labour productivity and efficiency of resource use of Polish enterprises of SME sector remains below the European average. Action is needed for the improvement of productivity and efficiency of resource use in the sector of small and medium-sized enterprises.

The subject literature says that conditionality in SMEs are conducive to the implementation of Lean concept, this is the prevailing view that such features as high flexibility and efficiency of the system of internal communication constitute about their advantage in this area over large companies, especially when it comes to the speed of implementing changes (Davenport, 1993; Wessel \& Burcher, 2004). In turn, characteristic for SMEs lack of formalized, methodical approach to strategic planning and focus on current problems leading usually to the adoption of a little ambitious assumptions, are not conducive to a clear definition of the relation between company goals and the need to implement changes. While the problem of Lean in SME sector is described in the literature, it mainly concerns medium-sized enterprises of the serial and of a little serial type of production rather than the small enterprises implementing often little serial or unit production (Nogalski \& Walentynowicz, 2011; Tyagia et al., 2015).

\section{PROBLEMS IN IMPLEMENTING THE LEAN CONCEPT}

The most common problem in implementing Lean concepts is lack of understanding of the concept itself and its principles. Here you can cite a similar situation during the implementation of quality assurance systems. The situation is well described by Roger Hall, chief executive officer of Tennant Company, USA (Hale, 1991): „We found that, like other important ideas, the idea of quality is very simple. As simple as it is difficult to understand."

Exactly with the same situation we are dealing with the concept of Lean with its rules and tools. The problem is the ability to look at the organization as a whole and understand own place in the organization and the impact that has on it, regardless of taken position.

Authors of the works (Atkinson, 2010; Liker \& Rother, 2011; Bortolottia et al., 2015) point to the very important role of organizational culture in the company in achieving success in implementing the Lean concept. The adoption by the company of socalled soft practices is another important element that determines the success of the implementation of Lean. Lean management is regarded as an approach that links with each other soft and hard practices (Fotopoulos \& Psomas, 2009; Calvo-Mora et al., 2013). Soft practices relate to people and relations while hard practices relate to the Lean techniques and analytical tools. Soft practices are essential to achieve the highest efficiency through Lean and to maintain productivity in the long perspective (Liker \& Rother, 2011). For enterprises of SMEs the weak side of organization culture is autocratic management style, which is not conducive to the improvement of processes by employees, and the lack of formalized, methodical approach to strategic planning and focus on current problems (Achanga et al., 2006). The multiplicity of functions, that employees fulfil, does not favour the analysis of problems arising in the processes which demands in-depth knowledge. Limited financial resources cause that changes made in the processes have temporary or short-term nature (Grudowski \& Leseure, 2013). In Poland it is accepted that the best way to reduce cost is to reduce the unit cost by increasing production volume, thereby the distribution of fixed costs across a larger number of products or reduction of employment, while maintaining the current course of processes (Ulewicz \& Mazur, 2015). Observing the state of Polish enterprises it can be seen that these methods are ineffective and meet with much resistance from employees who are forced to work more efficiently with unchanged conditions. Companies tend to forget that one person has a limited capacity and is not able to perform an unlimited number of operations per unit of time, and the faster one works, 
the more mistakes makes. This gives rise to the problem of the possibility to meet orders and customer demands in the situation of tightly limited resources. One of the solutions to this problem is deeper look at manufacturing processes and activities carried out in them and the methods used for their implementation. In the production and auxiliary processes you should therefore look for opportunities to meet the challenges of the market and the difficult economic situation of enterprises and eliminating waste (MUDs), (Womack \& Joan, 2003). A thorough understanding by the organizations of what client needs and what characteristics of a product or service will meet his expectations (price, delivery time, service), and search for a way to provide such a product, is the key to eliminate the waste and increasing productivity. The mistake, which is often made, is the inaccurate identification and definition of requirements of the external as well as internal customer. With such case we are dealing often in small and medium-sized enterprises that do not have the quality assurance system and operate on the basis of functional approach rather than process approach. The second problem is often a lack of stabilized production with which we are dealing in large enterprises. This situation means that both, the organization of such companies and their management, must significantly differ from practices used during the stabilized production in large companies. This is due to the fact that in such companies it is difficult to develop a plan of production and associated with it production schedule, taking into account the current production capacity of the company. Customer comes "when he wants", and orders a product which meets his individual needs, regardless of the plans and schedules.

The mistake that is often made is also inappropriate preparation of enterprise to implement Lean. This is due to the lack of culture of change and continuous improvement, lack of teamwork skills, frequent staff turnover, as well as piecework (Ohon, 2008; Baird et al., 2011). In case of small and medium-sized enterprises there is a serious problem of management or owner involvement in the process of implementing Lean. There is a belief that changes in the company are not needed when every-thing works well. Another mistake made by the management is forcing changes without consultation and the lack of explanation of the meaning of changes that are being implemented. Lack of long-term actions is another obstacle to the effective implementation of Lean concepts (Bicheno \& Holweg, 2009). Implementation of short-term projects often focuses on the short-term financial goals and limits the possibility of exchange of knowledge, ideas and information. In case of large companies and corporations there is also the problem of financial objectives and expectations in respect to the implementation of Lean. The result of such activities is the identification of Lean activities with a decrease in employment what results in an overall lack of confidence of workers to Lean operations that are being implemented. In extreme situations it reaches up to sabotage the improvement activities. It is a consequence of lack of training or inadequate Lean training that does not explain purposes and effects of realized actions. Another concern is that there is no definition of general indicators of the implementation of Lean concept, and no defined steps and measures of works progress (Fullerton et al., 2014). A common systemic mistake committed by the companies is the limitation of Lean concept to production department and the lack of clearly defined vulnerabilities of the system (for example Bottlenecks).

\section{RESEARCH METHODS}

For research a survey questionnaire consisting of 12 questions and metric identifying the respondent was used. Questions were selected in a manner enabling assessment of the impact of organization culture on the process of implementing Lean, the use of process approach, the use of soft Lean practices, as well as the techniques and tools of Lean. A separate question concerned the identified areas of wastefulness and problems in implementing the Lean concept.

In the process of acquiring responses research were conducted among the participants of V Open Lean Conference in Poznan. Per 500 distributed questionnaires, the survey returned 167 participants of the conference. The results of the research were supplemented with direct PAPI research (Paper and Pencil Personal Interview), (Gruszczyński, 2003) for small and medium-sized enterprises. During the study the interview with respondent was carried out, during which the interviewer read each question from the questionnaire and meticulously wrote down responses given by the respondent. In this way, 35 companies were surveyed. In the study was also 
used on-line questionnaire - CAWI (Computer Assisted Web Interview). CAWI technique consists in carrying out online survey supervised by the computer. In this way, the results were obtained from 40 companies. The respondents were managers of higher, middle and lower level and operational staff. In case of small and medium-sized enterprises business owners were also surveyed. For research there were qualified 65 companies of a separate group of small and medium-sized enterprises. Efforts were made, as far as possible, to give to the poll the workers of different levels within the same company. The main objective of carried out examinations was the assessment of functioning of Lean in small and medium-sized enterprises in Poland. In the study particular attention was paid to the impact of culture of the organization on the efficiency of implementation of Lean concept and problems in implementing the Lean in small and medium-sized enterprises.

\section{RESEARCH RESULTS}

Based on data from a questionnaire survey there was conducted classification of companies in terms of volume. The only distribution criterion was the number of employees. Fig. 1 shows the structure of the companies in which the questionnaire survey was conducted.

The next step was to recognize whether a given company knows the concept of Lean. If yes there was a question whether the company plans to implement Lean, or the company is already in the implementation stage. Based on the answers of respondents (in percentage share there were taken into account respondents from the same test facility) it was established that only $19 \%$ of the surveyed companies

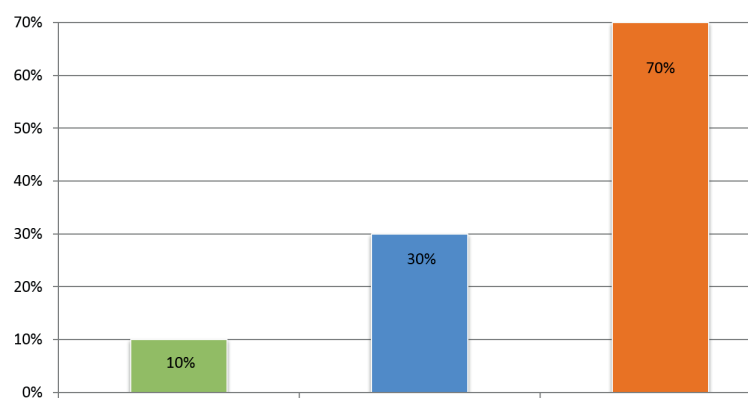

Fig. 1. Percentage share of companies participating in the survey research from a group of small and mediumsized enterprises [\%]

Source: author's elaboration.

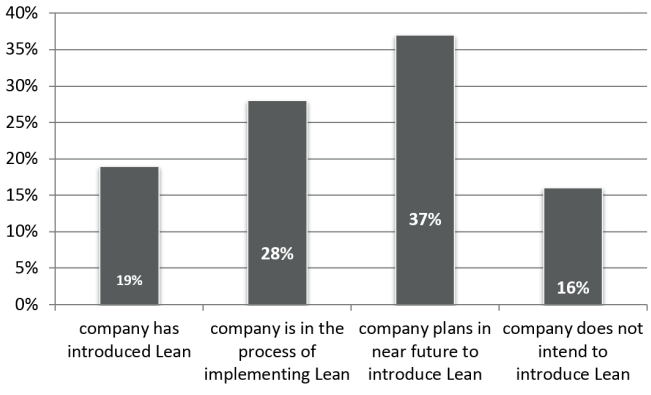

Fig. 2. The percentage share of companies participating in the survey from a group of small and medium-sized enterprises responding to the question about the level of involvement of companies in the implementation of Lean concept [\%]

Source: author's elaboration.

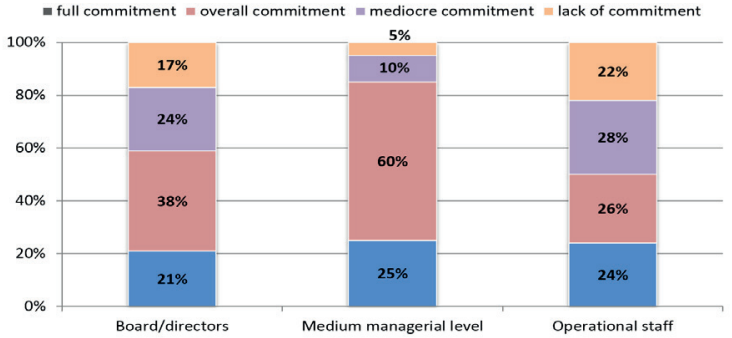

Fig. 3. Percentage structure of employees involvement in the process of implementing Lean concept [\%]

Source: author's elaboration.

from the SME sector implemented the concept of Lean and $28 \%$ is in the implementation stage. It is disturbing that nearly $16 \%$ of the surveyed companies do not know much about the issues of Lean or do know completely nothing and the questionnaire surveys is their first contact with the Lean term (this concerns $20 \%$ of the companies from $16 \%$ of analysed). The concept of process approach is also alien to them. Fig. 2 shows the structure of the answer to the question about the degree of involvement of the company in implementing the Lean concept.

For further analysis were qualified enterprises that have already implemented, are currently implementing or plan to implement the concept of Lean. When assessing the involvement of various groups of employees, we can conclude that the most involved in implementing Lean concept in the company are medium level employees ( $85 \%$ shows a strong commitment to implementing measures). The smallest degree of commitment we can observe in case of operational staff ( $50 \%$ shows mediocre or lack of commitment to implementing measures). Fig. 3 shows the percentage structure of given responses. Separate research group constitutes $16 \%$ of companies 


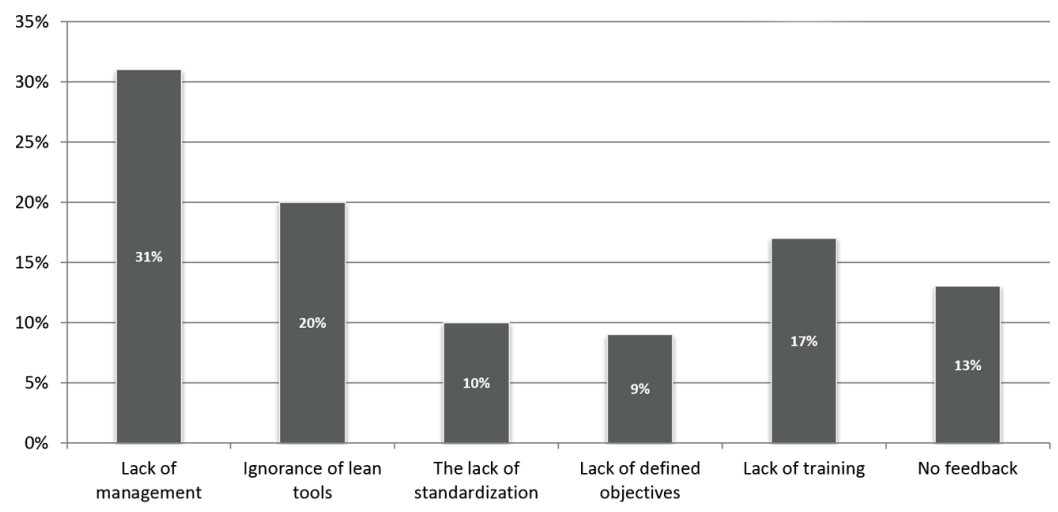

Fig. 4. Percentage structure of answers to the question about the problems in the implementation of Lean concept [\%]

Source: author's elaboration.

that do not plan to implement the concept of Lean to this group of companies direct interviews were addressed, which aimed at determining the reasons for the lack of interest in the concept of Lean. However, results obtained from conducted interviews are inconclusive and require additional testing of reasons for this state, which will be the aim of further research for the authors of the publication.

In the group of companies that have implemented the concept of Lean (19\% - of surveyed companies) and in the group of companies currently implementing the concept of Lean (28\%), 31\% of surveyed workers answered to open-ended question - What problems your company encountered during the implementation of Lean concept? Apparently the biggest problem is the lack of management involvement and failure to obey established standards. Another important problem reported by the respondents is the lack of knowledge of Lean tools ( $20 \%$ of responses) as a result of lack of training or improper training which was reported by $17 \%$ of respondents. Respondents also pointed to a problem with feedback regarding the effects of the implemented activities and their impact on the condition of the company (13\% of responses). Fig. 4 shows the structure of received responses to the question on the problems in implementing Lean concept.

\section{DISCUSSION OF THE RESULTS}

The scope of application of the concept of Lean in enterprises of SME sector, mainly depends on the nature of business activity, the type of production, applied technologies, and implementation stage of Lean concepts and professionalism of its use. An essential factor that requires additional study is a correlation level between the knowledge (about the tools and techniques of Lean) of people implementing this concept and the efficiency of implementation and maintenance of Lean. Very useful in the analysis of the survey data was a direct interview without which the image of the factual state of involvement of SMEs businesses was incomplete. Based on the received information we can draw thesis that one of the main reasons of problems in implementing Lean concepts is related to the lack of so-called soft practices directly related to the culture of the organization. In scope of hard techniques used within the concept of Lean a primary factor determining their efficiency is the nature of the production (stability/repeatability) than the industry which represents concerned undertaking. From conducted research also results the fact that in case of so-called apparatus production the use of hard techniques is often impossible and devoid of economic sense. Comparing obtained results with the results of research (Nguyen, 2015) you can indicate similarities in the scope of the role of soft techniques, however, important role play cultural determinants and experience of companies with concepts such as TQM or JIT (Baird et al., 2011), which in many cases especially for small businesses in Poland are unknown. The experience of the authors in the advisory activity for the improvement of production systems in ceramics, furniture, energy and electroplating sector of small and medium-sized enterprises indicates the need for very individual approach to the problems of implementation of Lean techniques. The big problem is a low level of staff preparation to use the tools supporting management processes and the difficulty in perceiving potential process improvement. The strength of SME enterprises is flat organizational structure, which considerably simplifies making changes, with the assumption that we have appropriately trained staff.

\section{CONCLUSIONS}

Conducted research indicate that small and medium-sized enterprises get on a big barrier in implementing Lean concept. The most common 
problems are inter alia: a barrier in relations between management and employees, lack of standardization, short-term financial goals, lack of information about the effects of activities and identification of Lean with a decrease in employment. Unfortunately, such an approach known as short-termism is a common mistake made by small and medium-sized enterprises. A big obstacle is the lack of knowledge of the techniques and tools used in Lean. As indicated by the respondents it is the result of lack of training or inadequate training detached from practice. In case of small and medium-sized enterprises problems in the implementation of Lean apply to a lesser extent technical issues, and to a greater extent management and control. This is related to the fact that in many cases the solutions applied in stable production, characteristic for large companies, cannot be used. Analysis of questionnaire surveys showed that there is great potential and demand for Lean solutions in the field of small and medium-sized enterprises. In Poland there are about 1.8 million companies out of which $99.8 \%$ are small and medium-sized enterprises. Based on questionnaire surveys, the most successful SMEs in implementing Lean in the analysed group have been found among enterprises employing more than 50 employees, and the least successful employing up to 10 employees. This is related to limited financial resources, which makes that the changes made in the processes in SMEs have temporary or short-term character and repeatedly take the form of inconsistent with each other projects.

\section{LITERATURE}

Achanga, P., Shehab, E., Roy, R., \& Nelder, G. (2006). Critical success factors for Lean implementation within SMEs. Journal of Manufacturing Technology Management, 17(4), 460-471.

Atkinson, P. (2010). Lean is a cultural issue. Management Services, 54, 35-44.

Baird, K., Hu, K., \& Reeve, R. (2011). The relationships between organizational culture,total quality management practices and operational performance. International Journal of Operations \& Production Management, 31(7), 789-814.

Bicheno, J., \& Holweg, M. (2009). The Lean Toolbox. The Essential Guide to Lean Transformation (4th edition). Buckingham, Great Britain: Production and Inventory Control, Systems and Industrial Engineering Books.

Bortolotti, T., Boscari, S., \& Danese, P. (2015). Successful Lean implementation: Organizational culture and soft Lean practies, International Journal Production Economics, 160, 182-201.
Calvo-Mora, A., Picón, A., Ruiz, C., \& Cauzo, L. (2013). The relationships between soft-hard TQM factors and key business results. International Journal of Operations \& Production Management, 34(1), 115-143.

Davenport, T. H. (1993). Process Innovation: Reengineering work through information technology. Boston, Massachusetts: Harvard Business School Press.

Deming, W. E. (1982). Out of the crisis. Cambridge, Great Britain: Massachusetts Institute of Technology.

Dora, M., \& Gellynck, X. (2015). Hause of Lean for food processing SMEs. Trends in Food Science \& Technology, 44, 272-281.

Dora, M., Kumar, M., Goubergena, D., Molnar, A., \& Gellynck X. (2013). Operational performance and critical success factors of Lean manufacturing in Europan food processing SMEs. Trends in Food Science \& Technology, 31, 156-164.

Engelund, E. H., Breum, G., \& Friis, A. (2009). Optimisation of largescale food production using Lean manufacturing principles. Journal of Foodservice, 20, 4-14.

Fotopoulos, C. B., \& Psomas, E. L. (2009). Theimpactof "soft" and "hard" TQM elements on quality management results. International Journal of Quality \& Reliability Management, 26(2), 150-163.

Fullerton, R. R., Kennedy, F. A., \& Widener, S. K. (2014). Lean manufacturing and firm performance: the incremental contribution of Lean management accounting practices. Journal of Operations Management, 32(7-8), 414-428.

Goncharuk, A. G. (2009). How to make meat business more effective: a case of Ukraine. British Food Journal, 111, 583-597.

Grudowski, P., \& Leseure, E. (2013). MSP LSS Plutus - Lean Six Sigma dla małych $i$ średnich przedsiębiorstw. Warszawa, Poland: WNT.

Gruszczyński, L. A. (2003). Kwestionariusze w socjologii [Questionnaires in sociology]. Katowice, Poland: Wydawnictwo Uniwersytetu Śląskiego.

Hale, R. L. (1993). Made in the U.S.A.: How One American Company Helps Satisfy Customer Needs Through Strategic Supplier Quality Management. Minneapolis, USA: Tennant Company.

Jadhav, J. R., Mantha, S. S., \& Rane, S. B. (2015). Roadmap for Lean implementation in Indian automotive component manufacturing industry. Journal of Industrial Engineering International, 11(2), 179-198.

Kleszcz, D., Ulewicz, R., \& Nowakowska-Grunt, J. (2013). The Use of Lean Tools in the Ceramic Industry. In Toyotarity. Management of the Production Values (pp. 94-111). Ankara, Turkey: Savas Kitap ve Yaymevi.

Liker, J. K., \& Rother, M. (2011). Why Lean Programs Fail. Lean Enterprise Institute. Retrieved from http://www.lean.org/Search/Documents/352.pdf

Mahalik, N. P., \& Nambiar, A. N. (2010). Trends in food packaging and manufacturing systems and technology. Trends in Food Science \& Technology, 21, 117-128. 
Nguyen, D. M. (2015). A new Application model of Lean management in small and medium sized enterprises. International Journal of Simulation Modelling, 14(2), 289-298.

Nogalski, B., \& Walentynowicz, P. (2011). Celowość zastosowania Lean Management w MSP [The desirability of the use of Lean Management in SMEs]. In Lachiewicz S., \& Matejun M. (Eds.), Zarzadzanie rozwojem małych $i$ średnich przedsiębiorstw [Management of the development of small and medium-sized enterprises]. Warszawa, Poland: Wydawnictwo Wolters Kluwer.

Ohno, T. (2008). System Produkcyjny Toyoty. Więcej niż produkcja na duża skale [Toyota Production System. More than the production on a large scale]. Wrocław, Poland: ProdPress.com.

Tyagia, S., Caib, X., Yanga, K., \& Chambers, T. (2015). Lean tools and methods to support efficient knowledge creation. International Journal of Information Management, 35, 204-214.

Ulewicz, R., \& Mazur, M. (2015). Doskonalenie transportu wewnętrznego $\mathrm{z}$ wykorzystaniem koncepcji lean studium przypadku [Improvement of Internal Transport by Means of LEAN Concept - Case Study]. Przegląd Organizacji, 7, 6-13.

Walentynowicz, P. (2013). Zakres zastosowania Lean Management $w$ przedsiębiorstwach produkcyjnych wyniki badań empirycznych. Innowacje w zarządzaniu $i$ inżynierii produkcji [Scope of application Lean Management in manufacturing companies - the results of empirical research. Innovation in the management and production engineering]. Opole, Poland: Oficyna Wydawnicza Polskiego Towarzystwa Zarządzania Produkcją.

Wessel, G., \& Burcher, P. (2004). Six Sigma for small and medium sized enterprises. The TQM Magazine, 16, 264-272.

Womack James, P., \& Joan Daniel, P. (2003). Lean Thinking: Banish Waste and Create Wealth in Your Corporation. London, Great Britain: Revised and Updated Hardcover, Simon\&Schuster.

Zadura-Lichota, O., \& Tarnawa, A. (Eds.). (2014). Raport o stanie sektora matych $i$ średnich przedsiębiorstw $w$ Polsce $w$ latach 2012-2013 [The report on the state of small and medium enterprises in Poland in 20122013]. Warszawa, Poland. 